\title{
Mapping of Reproduction Disorders Caused by Infectious Diseases in Bali Cattle (Bos sundaicus) in Muna Regency, Indonesia
}

Achmad S. Aku ${ }^{1}$, Yamin Yaddi ${ }^{1}$, Takdir Saili', Harapin Hafid ${ }^{1}$,

La Ode M. Munadi ${ }^{1}$, Fitria Dewi², Surya C.R. Kete ${ }^{3}$

10.18805/IJAR.BF-1424

\begin{abstract}
Background: The Government of Muna Regency, Southeast Sulawesi Province, in Indonesia, made Bali cattle a leading livestock commodity. The problem faced by farmers is the slow increase in population, which is caused by reproduction disorders. Mapping of animal diseases can be used as a guide in determining the location of cattle farming development. This study aims to determine the spread of infectious diseases found in Bali cattle in the Muna Regency. A total of 27 blood samples were obtained from the jugular veins of the cattle in Muna Regency in 9 sub-districts, that were suspected to have an infectious disease.

Methods: The samples were then tested using the ELISA method for Septicaemia epizootica, Infectious Bovine Rhinotracheitis and Trypanosomiasis, while the test for Brucellosis was conducted in parallel between RBT and CFT.

Result: Brucellosis and Infectious Bovine Rhinotracheitis were absent, however, the prevalence of Septicaemia epizootica disease was in all regions. Trypanosomiasis disease is found in $55.5 \%$ of Bali cattle breeding centers in Muna Regency, in adjacent areas, Septicaemia epizootica was the disease with the highest rate of infection followed by Trypanosomiasis which was partial in some regions.

Key words: Bali cattle, Infectious diseases, Reproduction disorders.
\end{abstract}

\section{INTRODUCTION}

Bali cattle are one of the local germplasm of Indonesian beef cattle (Purwantara et al., 2012) that needs to be developed through a gradual, directed and sustainable increase in population. This is because it has several advantages compared to other local Indonesian cattle such as rapid growth (Labatar and Aswandi, 2017), good reproductive performance, (Hakim et al., 2008) and ability to adapt to the environment.

Bali cattle migrated from Bali island to South Sulawesi in 1920 and 1927. Southeast Sulawesi is one of the regions in Indonesia that is the center of development of beef cattles. According to (BPS Sultra, 2018), Muna Regency ranks first in the beef cattle population of 56,596 . Therefore, the Government made beef cattles a leading livestock commodity. Nine subdistricts are designated as centers for increasing the population of beef cattle, especially in Muna Regency, namely, Napabalano, Watopute, Lasalepa, Bone, Parigi, Kabawo, Kabangka, Tongkuno and South Tongkuno Subdistricts (Saili et al., 2018).

Based on the animal disease monitoring report by the Muna District Livestock Office (2018), it was stated (Saili et al., 2018) that the incidence of disease in large ruminant livestock include Injury (832 cases), Tympani (135 cases), Miasis (498 cases), Scabiesis (495 cases), Helmintiasis (2946 cases), Thaleziasis (2581 cases) Dystocia (35 cases), Poisoning (62 cases) and Reproductive Disorders (120 cases). There have been no reports on the incidence and spread of infectious reproductive diseases caused by factors either directly or indirectly affecting the reproductive performance of Bali cattle in the Muna Regency.
${ }^{1}$ Faculty of Animal Science, Halu Oleo University, Indonesia.

${ }^{2}$ Faculty of Mathematics and Natural Science, Halu Oleo University, Indonesia.

${ }^{3}$ Faculty of Forestry and Environmental Science, Halu Oleo University, Indonesia.

Corresponding Author: Achmad S. Aku, Faculty of Animal Science, Halu Oleo University, Indonesia.

Email: achmad.s.aku@uho.ac.id

How to cite this article: Aku, A.S., Yaddi, Y., Saili, T., Hafid, H., Munadi, L.O.M., Dewi, F. and Kete, S.C.R. (2022). Mapping of Reproduction Disorders Caused by Infectious Diseases in Bali Cattle (Bos sundaicus) in Muna Regency, Indonesia. Indian Journal of Animal Research. DOI: 10.18805/IJAR.BF-1424.

Submitted: 13-08-2021 Accepted: 01-01-2022 Online: 09-02-2022

Reproductive disorders caused by infectious factors commonly found in Bali cattle farms in Indonesia are Trypanosomiasis (Sulaeman et al., 2019), Brucellosis (Muflihanah et al., 2013), Septicemia Epizootica (Berek et al., 2015) and Infectious Bovine Rhinotracheitis (Adjid, 2004). Furthermore, some of them are included in the type of infectious reproductive diseases that needs to be handled properly because they would interfere with the reproduction process.

\section{MATERIALS AND METHODS}

This research was conducted from June to November, 2020. The research locations were conducted in 6 sub-districts in Muna Regency, Southeast Sulawesi, Indonesia. The sample types used in this study were blood collected from the jugular 
veins of Bali cattles (multy ages) with clinical symptoms of Brucellosis, Septicemia epizootica (SE), Infectious Bovine Rhinotracheitis (IBR) and Trypanosomiasis. A total of 27 samples were collected from suspected areas where the disease was believed to originate from. The collected samples were then analyzed on Balai Besar Veteriner Maros.

The blood samples were tested using the Rose Bengal Test (RBT) and complement fixation test (CFT conducted in parallel for disease testing Brucellosis. The positive results of RBT were further tested with the CFT method. This test was based on the procedure performed by (Godfroid et al., 2010). The ELISA test is also used to detect the incidence of SE, IBR and Trypanosomiasis by following the work procedures carried out by (Lequin 2005).

Spatial analysis was used in determining the patterns and spread of animal diseases in the research area. The first disease mapping was conducted by Jhon Snow in 1849 by isolating the region based on the incidence of cholera in England (Hay et al., 2013; Barford and Dorling, 2016) In this study, the data analysis techniques were used in the form of buffer and overlay analysis. The Buffer technique was used to identify and limit the study area, while overlay was used in presenting the data integration results from both primary and secondary data.

\section{RESULTS AND DISCUSSION}

Test results for 27 samples in Brucellosis, Trypanosomiasis, IBR and SE showed mixed results and different incidence rates. Furthermore, Brucellosis and IBR diseases showed negative results, while SE and trypanosomiasis had a prevalence of $100 \%$ and $55.66 \%$ respectively (Table 1 ).

The first report of brucellosis in Indonesia was in 1915 (Novita, 2016). In 2012 this disease was present in the islands of Sulawesi with $21.9 \%$ prevalence in South Sulawesi (Muflihanah et al., 2013). The incidence of Brucellosis poses a threat to the development of cattle farms. The main predisposes factors that make this disease transmitted rapidly in Indonesia are maintenance patterns especially in traditional systems (Nugroho et al., 2019), low preventive measures (vaccination) (Martindah and Noor, 2018) and improper post parturition handling (AvilaCalderón et al., 2013).

Table 1 shows that the incidence of SE reached about $100 \%(27 / 27)$ in the Bali cattle development area in Muna Regency. It is caused by Pasteurella multocida which is an infectious disease that is acute in cattle and buffalo and causes considerable economic loss (Benkirane and De

Table 1: Results of serological testing of Bali cow blood samples in Muna Regency.

\begin{tabular}{lccc}
\hline $\begin{array}{l}\text { Types of } \\
\text { diseases }\end{array}$ & $\begin{array}{c}\text { Number of } \\
\text { samples }\end{array}$ & Positive & $\begin{array}{c}\text { Sample } \\
\text { presentations (\%) }\end{array}$ \\
\hline Brucellosis & 27 & 0 & 0 \\
SE & 27 & 27 & 100 \\
Trypanosomiasis & 27 & 15 & 55.56 \\
IBR & 27 & 0 & 0 \\
\hline
\end{tabular}

Alwis, 2002). Reproductive disorders due to this disease occur indirectly due to spontaneous weight loss (abortus) (Saminathan et al., 2016) and fertility failure due to decreased nutrient intake (Chung et al., 2015).

Septicemia epizootica is widely reported in tropical countries especially in Asia and Africa (Benkirane and De Alwis, 2002). This was first reported in Indonesia in 1884 in Balaraja and Tangerang (Yohanes and Theresia, 2012). Furthermore, It was stated that SE is endemic in several beef cattle development areas in Indonesia such as Nusa Tenggara and Sulawesi Island (Agustini et al., 2014). In general Pasteurella multocida found in Asia including Indonesia comes from serotype B (Orynbayev et al., 2019) which was later developed into an isolate vaccine (Dabo et al., 2008) to prevent the spread (Mostaan et al., 2020).

Trypanosomiasis is caused by blood endoparasites (Trypanosoma $s p$ ) which lead to premature birth and infertility (testicular damage) and decreased milk production (Mamoudou et al., 2016). The results of this study showed $55.56 \%$ incidence of this disease (15/27) in some areas in Muna Regency. Trypanosomiasis is mechanically transmitted by blood-sucking flies and their influence on the host varies depending on certain factors, namely the effectiveness of transmission by mechanical vectors, suitability, the vulnerability of the host and the ability of parasites to adapt (Misra et al., 2016). The host of Trypanosoma evansi ranges from wild to domestic animals. Examples of domestic animals that are susceptible to surra disease include horses, cows, buffaloes, goats, sheep, pigs, dogs and cats.

The results of this study showed that Muna District has not been exposed to Bovine Herpesvirus 1 (BHV-1) which is the major cause of Infectious Bovine Tracheitis disease in ruminant animals. In Indonesia, the incidence of IBR disease has been reported in several areas of beef cattle development centers such as in Sumatra (Aceh and North Sumatra), Java, Sumbawa and Nusa Tenggara (Hidayati et al., 2019). It was first reported in Indonesia in 1982 by the Center for Animal Disease Investigation region III Lampung in collaboration with JICA, using a neutralization serology test (Kristianingrum et al., 2015). Furthermore, the Center for Veterinary Research, Bogor also reported that in 1985 , the IBR isolates serologically came from imported cows and buffaloes. According to the study by (Damayanti and Sudarisman, 2005), it was stated that Bali cattle are species that are susceptible to $\mathrm{BVH}-1$ even though the clinical symptoms begin to disappear 21 days after infection, with the main source of infection coming from exposed bull semen. Transmission could occur through natural mating or artificial insemination (Al) (Nandi et al., 2009).

The farming community in Muna Regency sees farming as a side job and livestock as a form of investment. Furthermore, breeding culture are found in regions where cattle are released wild on grazing or plantation lands (extensive). Therefore, this study focused on the pattern of disease spread in several subdistricts that are the center of Bali cattle development. Two main factors that influence the spread of disease in livestock include (1) climate relationship 


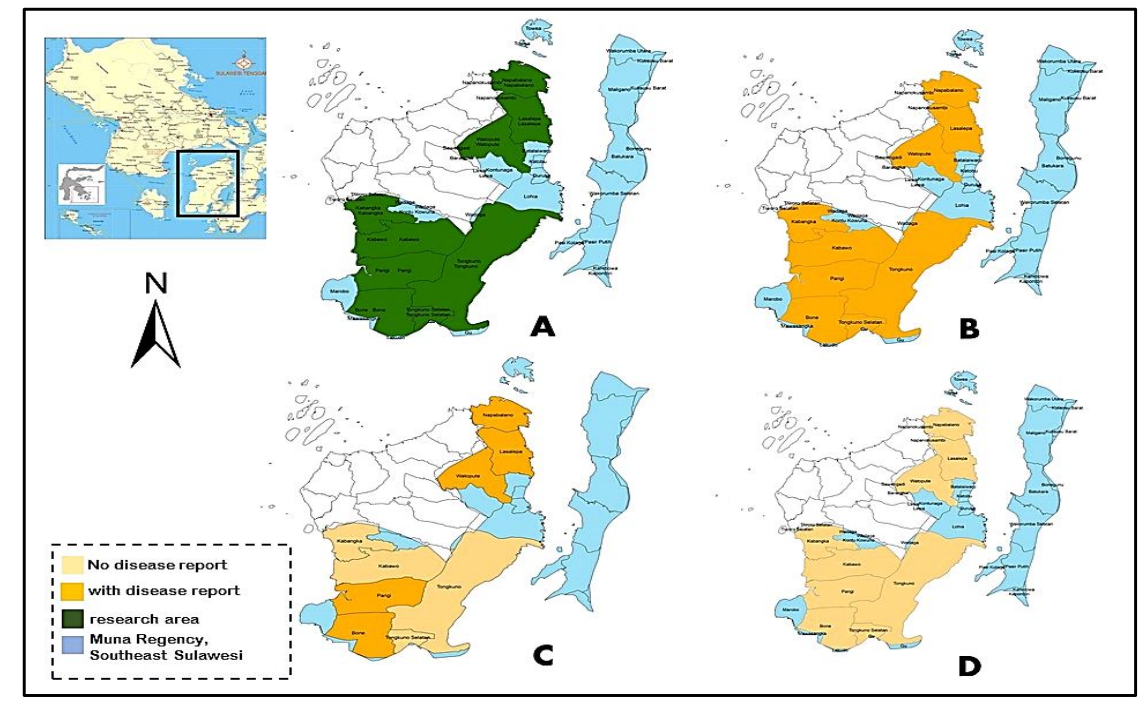

Fig 1: Map of the spread of infectious animal diseases (Brucellosis, SE, IBR and Trypanosomiasisa) on cattle in each subdistrict in Muna. The study area (A), the spread of SE disease (B), the spread of Trypanosomiasis disease (C) and incidence of Brucellosis and IBR (D).

with ecosystem balance, especially the pattern of activity of disease-causing microorganisms, (2) globalization concerning maintenance patterns where there is a shift in land use due to trading activities, population growth and food supply chain (Wilkinson et al., 2011).

The results of this study showed that SE was the disease with the highest form of contraction and its incidence was found in all study areas. Furthermore, the diseases with a high rate of infection were found in Tryphanosomiasis with $55.56 \%$ occurrence and it only occurred in some subdistricts. There was also no incidence of Brucellosis and Infectious Bovine Tracheitis diseases (Fig 1).

The overlay results on the spread of disease and regional ecosystems show that the reports of SE and Trypanosomiasis in Bali cattle are commonly found in coastal typology. Furthermore, climate factors contribute to the spread of livestock diseases. This region has a total rainfall of 1188 $\mathrm{mm} /$ year with an average air temperature of $27,15^{\circ} \mathrm{C}$ and humidity of $80.30 \%$ (BPS Sultra, 2020). These conditions fall into the category of dry climate which has a negative impact on the limitations of feed and water resources for livestock and results in malnutrition and weight loss. Malnutrition is one of the leading causes of Trypanosoma evansi infection (Reid et al., 2001). It has the potential to increase when cases in the region are not immediately resolved because it is acute and contagious in ruminants. Therefore, it is believed that the disease of SE and Trypanosomiasis is still the main problem that farmers experienced and they are characterized by their high rate of infection.

\section{CONCLUSION}

The concluded that Septicemia Epizootica and Trypanosomiasis were the diseases with the highest rate of infection and, the Muna district was still free of Brucellosis and Infectious Bovine Rhinotracheitis.

\section{ACKNOWLEDGEMENT}

The author is grateful to the Government of Muna Regency, Southeast Sulawesi Province for funding this research.

\section{Conflicts of interest: None.}

\section{REFERENCES}

Adjid, R.M.A. (2004). Alternative strategies for control of infectious reproductive diseases to improve reproductive efficiency of beef cattle. Wartazoa. 14(3): 125-132.

Agustini, NLP.,Supartika I.K.E. and J. Uliantara, IGA. (2014). Laporan kasus septicaemia epizootica pada sapi bali di kabupaten timor tengah utara provinsi nusa Tenggara Timur Tahun 2014. Buletin Veteriner, BBVet Denpasar, Vol. XXVI, No. 85, December 2014 ISSN/ : 0854-901X. $X X V I(85), 1-10$.

Avila-Calderón, E.D., Lopez-Merino, A., Sriranganathan, N., Boyle, S.M., Contreras-Rodríguez, A. (2013). A history of the development of Brucella vaccines. BioMed Research International, 2013 (June). https://doi.org/10.1155/2013/743509.

Barford, A. and Dorling, D. (2016). Mapping Disease Patterns. Wiley Stats Ref: Statistics Reference Online, April, 1-15. https:/ /doi.org/10.1002/9781118445112.stat06102.pub2

Benkirane, A. and De Alwis, M.D.L. (2002). Haemorrhagic septicaemia, its significance, prevention and control in Asia. Veterinarni Medicina. 47(8): 234-240. https://doi.org/ 10.17221/5830-Vetmed.

Berek, H.S.D., Nugroho, W.S., Wahyuni, A.E.T. (2015). Cattle Protection in Kupang Regency Against Snoring Disease (Septicaemia epizootica). Jurnal Veteriner. 16(2): 167-173.

Central Statistics Agency Southeast Sulawesi. (2018). Sulawesi Tenggara Dalam Angka Tahun 2020. In BPS Sultra 2020. Kendari.

Chung, E.L.T., Abdullah, F.F.J., Adamu, L., Marza, A.D., Ibrahim, H.H., Zamri-Saad, M., Haron, A.W., et al. (2015). Clinicopathology, hematology and biochemistry responses toward Pasteurella multocida Type B: 2 via oral and subcutaneous 
route of infections. Veterinary World. 8(6): 783-792. https://doi.org/10.14202/vetworld.2015.783-792.

Dabo, S.M., Taylor, J.D. Confer, A. W. (2008). Pasteurella multocida and bovine respiratory disease. Animal Health Research Reviews. 8(2): 129-150. https://doi.org/10.1017/ S1466252307001399.

Damayanti, R. and Sudarisman. (2005). Pathogenicity of local isolate of BHV-1 virus as the cause of infectious bovine rhinotracheitis (IBR) in Bali cattle. Jurnal IImu Ternak dan Veteriner. 10(3): 227-235.

Godfroid, J., Nielsen, K., Saegerman, C. (2010). Diagnosis of Brucellosis in livestock and wildlife. Croatian Medical Journal. 51(4): 296-305. https://doi.org/10.3325/ cmj.2010.51.296

Hakim, L., Suryadi, Nuryadi, A.M., Susilawati, T., Nurgiartiningsih, A. (2008). Development of Bali cattle breeding management system. Sains Peternakan. 6(1): 9-17.

Hay, S.I., Battle, K.E., Pigott, D.M., Smith, D.L., Moyes, C.L., Bhatt, S., Brownstein, J.S., Collier, N., Myers, M.F., George, D.B., Gething, P.W. (2013). Global mapping of infectious disease. Philosophical Transactions of the Royal Society B: Biological Sciences. 368(1614). https://doi.org/ 10.1098/rstb.2012.0250

Hidayati, D.N., Srihanto, E.A., Untari, T., Wibowo, M.H., Akiyama, K., Asmara, W. (2019). The establishment of PCR amplification, cloning and sequencing of bovine herpesvirus 1 (BHV-1) glycoprotein D gene isolated in Indonesia. Indonesian Journal of Biotechnology. 24(1): 34-42. https://doi.org/10.22146/ijbiotech.44298

Kristianingrum, Y., Tabbu, C., Sutrisno, B., Widyarini, S., Kurniasih, K., Untari, T., Kusumawati, A. (2015). Immunohistochemistry Detection of Bovine Herpesvirus-1 in Corioallantoic Membrane of Chicken Embryonated Egg. Jurnal Veteriner. 16(4): 483-488. https://doi.org/ 10.19087/ jveteriner.2015.16.4.483.

Labatar, S.C. and Aswandi. (2017). Maintenance System, Population Structure of Bali Cattle in People's Farms, Manokwari Regency. East Papua Province. Jurnal Triton. 8(1): 93-107.

Lequin, R.M. (2005). Enzyme immunoassay (EIA)/enzyme-linked immunosorbent assay (ELISA). Clinical Chemistry. 51(12): 2415-2418. https://doi.org/10.1373/clinchem. 2005.051532

Mamoudou, A., Njanloga, A., Hayatou, A., Suh, P.F., Achukwi, M.D. (2016). Animal Trypanosomosis in clinically healthy cattle of north Cameroon: Epidemiological implications. Parasites and Vectors. 9(1): 1-8. https://doi.org/10.1186/ s13071-016-1498-1.

Martindah, E. and Noor, S. (2018). Seroepidemiology of Brucellosis on Dairy Cattle In Smaal-Holders Farms, In West Java (pp. 89-97).

Misra, K.K., Roy, S., Choudhury, A. (2016). Biology of Trypanosoma (Trypanozoon) evansi in experimental heterologous mammalian hosts. Journal of Parasitic Diseases. 40(3): 1047-1061. https://doi.org/10.1007/s12639-014-0633-1.

Mostaan, S., Ghasemzadeh, A., Sardari, S., Shokrgozar, M.A., Brujeni, G.N., Abolhassani, M., Ehsani, P., Karam, M.R.A. (2020). Pasteurella multocida vaccine candidates: A systematic review. Avicenna Journal of Medical Biotechnology. 12(3): 140-147.
Muflihanah, H., Hatta, M., Rood, E., Scheelbeek, P., Abdoel, T.H., Smits, H.L. (2013). Brucellosis seroprevalence in Bali cattle with reproductive failure in South Sulawesi and Brucella abortus biovar 1 genotypes in the Eastern (November 2013). https://doi.org/10.1186/1746-6148-9233.

Nandi, S., Kumar, M., Manohar, M., Chauhan, R.S. (2009). Bovine herpes virus infections in cattle. Animal Health Research Reviews/Conference of Research Workers in Animal Diseases. 10(1): 85-98. https://doi.org/10.1017/S14662 52309990028.

Novita, R. (2016). Brucellosis: A neglected zoonotic disease. Balaba: Jurnal Litbang Pengendalian Penyakit Bersumber Binatang Banjarnegara. 12(2): 135-140. https://doi.org/10.22435/blb.v12i2.4625.135-140.

Nugroho, D.K., Syibli, M., Schoonman, L., Pfeiffer, D., Chanachai, K., Punyapornwithaya, V. (2019). Evaluation of the Indonesian Animal Brucellosis Surveillance System in 2016 using the Outild'analyse des systèmes de surveillance (OASIS) Method. Osir. 12(2): 46-53.

Orynbayev, M., Sultankulova, K., Sansyzbay, A., Rystayeva, R., Shorayeva, K., Namet, A., Fereidouni, S., Ilgekbayeva, G., Barakbayev, K., Kopeyev, S., Kock, R. (2019). Biological characterization of Pasteurella multocida present in the Saiga population. BMC Microbiology. 19(1): 1-10. https://doi.org/10.1186/s12866-019-1407-9.

Purwantara, B., Noor, R. andersson, G., Rodriguez-Martinez, H. (2012). Banteng and Bali Cattle in Indonesia: Status and Forecasts: Bali Cattle Breeding: State of the Art. Reproduction in Domestic Animals. 47, 2-6. https:// doi.org/10.1111/j.1439-0531.2011.01956.x

Reid, S. A., Husein, A., Copeman, D. B. (2001). Evaluation and improvement of parasitological tests for Trypanosoma evansi infection. Veterinary Parasitology. 102(4): 291297. https://doi.org/10.1016/S0304-4017(01)00539-8

Saili, T., Zulkarnain, D., Aku AS, R, L., Kete, S., Y, Y., Fitria, D. (2018). Strategic Disease Mapping in Cattle Supports Siwab Program in Muna District. Final Research Report, 168 hal.

Saminathan, M., Rana, R., Ramakrishnan, M., Malik, Y., Dhama, K. (2016). Journal of Experimental Biology and Agricultural Sciences Prevalence, Diagnosis, Management and Control of Important Diseases of Ruminants with Special Reference to Indian Scenario. Journal of Experimental Biology and Agricultural Sciences. 4(3S)(2320).

Sulaeman, N.S., Sunarso, A., Agustono, B., Hastutiek, P., Saputro, A.L., Yudhana, A. (2019). Surra Disease Prevalence in Beef Cattle in Cluring District Banyuwangi. Jurnal Medik Veteriner. 2(1): 42. https://doi.org/10.20473/jmv.vol2.iss 1.2019.42-48.

Wilkinson, K., Grant, W.P., Green, L.E., Hunter, S., Jeger, M.J., Lowe, P., Medley, G.F., Mills, P., Phillipson, J., Poppy, G. M., Waage, J. (2011). Infectious Diseases of Animals and Plants: An Interdisciplinary Approach. Philosophical Transactions of the Royal Society B: Biological Sciences. 366(1573): 1933-1942. https://doi.org/10.1098/rstb. 2010.0415.

Yohanes, T.R.M. R.S. and Theresia, F.I.M.D.M. (2012). Occurrence of Septicemia epizzotica in Cattle in Kupang Regency in 2005-2011. Sain Veteriner. 30(2): 53-60. 